\title{
The Ethics of Authenticity
}





\section{The Ethics of Authenticity Charles Taylor}

Harvard University Press

Cambridge, Massachusetts and London, England 
(c) 1991 by Charles Taylor and the Canadian Broadcasting Corporation All rights reserved

Printed in the United States of America

First Harvard University Press paperback edition, 2018 First printing

Originally published in Canada in 1991 under the title The Malaise of Modernity, an extended version of the 1991 Massey Lectures, which were broadcast in November 1991 as part of CBC Radio's Ideas series.

This book is printed on acid-free paper. Library of Congress Cataloging-in-Publication Data Taylor, Charles, 1931-

The ethics of authenticity / [Charles Taylor]. p. cm.

Includes index.

ISBN 978-0-674-26863-0 (cloth : alk. paper) ISBN 978-0-674-98769-2 (pbk.)

1. Self-realization-Social aspects. 2. Civilization, ModernPsychological aspects. 3. Social values-History. I. Title.

BF637.S4T39 1992

$320^{\prime} .01-\mathrm{dc} 20$

92-9179

CIP 